\title{
ERRORS ANALYSIS OF LANGUAGE FUNCTIONS USED BY THE LOCAL GUIDES IN DANAU TAMBLINGAN BULELENG BALI
}

\author{
P.G.E. Thiana ${ }^{1}$, I.G. Budasi ${ }^{2}$, N.P.A. Pratiwi ${ }^{3}$ \\ English Education Department, Ganesha University of Education, Singaraja \\ e-mail: putugedeelmanthiana@gmail.com,gede.budasi@undiksha.ac.id, astitipratiwi@undiksha.ac.id
}

\begin{abstract}
Abstrak
Penelitian ini bertujuan untuk mengidentifikasi fungsi bahasa, menganalisis jenis-jenis kesalahan dan mengidentifikasi sumber kesalahan yang dilakukan oleh pemandu wisata di Danau Tamblingan. Penelitian ini adalah penelitian kualitatif deskriptif. Subyek penelitian ini adalah tiga pemandu lokal di Danau Tamblingan. Data dikumpulkan melalui observasi dan wawancara. Model analisis data interaktif digunakan untuk menganalisis data. Hasil penelitian ini menunjukkan bahwa 14 fungsi bahasa ada yang memberi nasihat, berterima kasih, menyapa, menolak, pengenalan diri, menawarkan sesuatu, meminta informasi, memberikan informasi, menjelaskan sesuatu, memberi saran, memberi perintah, memberitahu larangan, meminta maaf, dan mengucapkan selamat tinggal. Ada 4 jenis kesalahan: omission, addition, misformaition, dan misordering. Jumlah total kesalahan adalah 579 yang terdiri dari kesalahan 365 atau $63,0 \%$ pada omission, 103 kesalahan atau $19,0 \%$ pada addition, 93 kesalahan atau 15\% dalam misformation atau dan 18 kesalahan atau 3,0\% dalam misordering.
\end{abstract}

Kata kunci: Fungsi Bahasa, Error, Pemandu Lokal, Bahasa Inggris

\begin{abstract}
This study was aimed at identifying the language functions, analyzing the types of errors in and identifying the sources of errors committed by local guides in DanauTamblingan. This study was a descriptive qualitative research. The subjects of this study were three local guides in DanauTamblingan. The data were collected through observation and interview. Interactive data analysis model was used to analyze the data. The results of this study show that 14 language functions namely advising, thanking, greeting, refusing, self-introduction, offering something, asking information, giving information, explaining something, giving suggestion, giving command, telling prohibition, apologizing, and saying goodbye. There were 4 types of error: omission, addition, misformation and misordering. The total number of errors were 579 which consisted of 365 errors or $63.0 \%$ in omission, 103 errors or $19.0 \%$ in addition, 93 errors or $15 \%$ in misformation and 18 errors or $3.0 \%$ in misordering.
\end{abstract}

Keywords: language function, errors, Local guide, English

\section{Introduction}

DanauTamblingan is one of the lakes in Bali which is located at the foot of Mount Lesung in DesaMunduk, Buleleng Regency, Bali. DanauTamblingan is also near DanauBuyan and DanauBeratan. It is surrounded by a conservation forest which gives a natural view and fresh air. Around DanauTamblingan, there are many Balinese temples which have their own histories about the development of civilization and culture in. It makes DanauTamblingan become one of the best tourism places in North Bali.

DanauTamblingan is one of the lakes in Bali which is located at the foot of Mount Lesung in DesaMunduk, Buleleng Regency, Bali. DanauTamblingan is also near 
DanauBuyan and DanauBeratan. It is surrounded by a conservation forest which gives a natural view and fresh air. Around DanauTamblingan, there are many Balinese temples which have their own histories about the development of civilization and culture in. It makes DanauTamblingan become one of the best tourism places in North Bali.

DanauTamblingan is developed as a natural and spiritual tourism object. There are some activities for natural tourism in DanauTamblingan, such as camping, tracking, fishing, and others. Those activities utilize the natural potential of DanauDanauTamblingan. In spiritual tourism, the tourists can visit and pray in the temples around DanauTamblingan. The tourists also can get some information about the place and guidance in DanauTamblingan while they enjoy the natural and spiritual tourism. Both natural and spiritual tourism attract both local and foreign tourists to come there.

The development of tourism object in the DanauTamblingan accompanied by improving services to the tourists. There is a group named KelompokSadarWisata "TAMBA ELING" DesaGoblegPramuwisataAmertaJati which provides guides for local and foreign tourist. Tour guide or local guides is really needed as someone who gives explanation and guidance to the tourist when visiting an object or tourist area (Pond, 1993). So, the local guide is needed in DanauTamblinganto improve the service. The local guide will lead the tourist to some spots in DanauTamblingan. The local guide will give some information about the situation and histories of the temples in DanauTamblingan. The local guides also give some guidances to the tourists about what things that they can do in DanauTamblingan. Providing local guides is important for tourism in DanauTamblingan.

Furthermore, providing a good service to the tourist is not only about providing the local guide but the quality of the local guide in DanauTamblingan should have a standard. According to Chilembwe\&Mweiwa (2014), traveling becomes more enjoyable when a welltrained guide is presented. Tour guides or local guides are knowledgeable like teachers, hence impart knowledge and give travelers the right information about a destination. In DanauTamblingan, a professional tour guide or local guides is really important for tourism itself. They should have knowledge of guest, the knowledge about culture, place, object, event, and product. In delivering the idea when the local guides are explaining something to the tourist, they should have good language skills to communicate.

In handling a tourist, a local guide needs to know about several kinds of language functions for helping him/her communicate well to the tourists. Kanya (2017) found several language functions that were used while handling the tourist by the tour guide, such as greeting, thanking, apologizing, offering something, saying goodbye, etc. Those language functions should be mastered because they help the local guides to communicate to the tourists.

The researcher had already gone to DanauTamblingan. The researcher found some foreigners with the local guide who was explaining something. Accidentally, the researcher heard some errors in local guide's English while he was explaining to the tourists. The researcher wanted to know more about the problems until the researcher heard for the second time for other local guides who used grammatically incorrect sentences while they were explaining about the DanauTamblingan.

Based on what the researcher found in the field, some of the local guides used grammatically incorrect sentences for explaining about DanauTamblingan. They formed sentences in English as they formed in their mother tongue which are Balinese and Indonesian. Because of that, the use of English by the local guide in DanauTamblingan used Balinese or Indonesian structure. It made the English that was used by the local guide had a different structure.

As the phenomenon that researcher found in the field, the local guide usually said "this very natural view". According to Ricard as cited in (Heydari\& Bagheri, 2012), intralingual is an error in applying the rules of the target language. Based on the definition, the local guide had an error in applying the rules in the target language because the sentence was not complete yet. There were omissions of be and article. The sentence showed that the local 
guide used a grammatically incorrect sentence to communicate with the tourists and the local guides did not consider the standard English for their communication.

Based on the analysis about the phenomena that happened between local guides and foreigners, this study was really important to be conducted because if those errors are not noticed well, it will bring a negative impact for the tourism itself. This study was conducted in order to find out the error sentences formed especially for language functions that used by local guides while explaining the tourism place. It was expected that this research would give useful information as an additional source for English Specific Purpose, Instructor of ESP and for further similar research.

This study used several theories to analyzed the data, such as language function, types of error, source of error. Language functions are known as functionalist which describe and represent the active use of language for a specific purpose (Newmeyer, 2003). Related to this study, the tour guides used the language functions in servicing the tourists. According to Savignon as quoted in Kusumayati (2011) and also quoted in Andayani (2013), the function of language refers to things the speakers do with their language in communication, for example: agreeing, disagreeing, greeting, giving command, leave-taking, describing, and asking for information

Moreover, Language functions refer to the purposes in which we use language to communicate. According to the Spratt, Pulverness, and Williams (2005) there are some examples of language function, such as apologizing, advising, thanking, greeting, agreeing, interrupting, clarifying, disagreeing, inviting, and refusing.

Furthermore, related to this study there were several language functions that used by the guide in servicing the guest (Sucipta, 2016). Those are greeting, self-introduction, offering something, asking information, giving information, indicating something, explaining something, asking permission, giving suggestion, telling prohibition, apologizing, thanking, and saying goodbye. Based on those theories above, it can be concluded that there are some language functions such as agreeing, disagreeing, greeting, giving command, leave taking or saying goodbye, describing or explaining something, apologizing, advising, thanking, interrupting, clarifying, inviting, refusing, self-introduction, offering something, asking information, giving information, indicating something, asking permission, giving suggestion, and telling prohibition.

The errors committed by the local guide had been analyzed using theory of error. In analyzing the errors, the meaning of error should be understood clearly in order to distinguish between error and mistake. According to Pelin (2010), error and mistake are different. Error occurs for several times in the same false, while mistake occurs not in one point and it is more random. An error comes when the user has lack knowledge about the language target. Moreover, according to Gass and Selinker (2001), error systematically occurs and it is repeated unconsciously, while, a mistake occurs one-time-only events. Based on those theories, an error is falsity that occurs systematically, but mistake occurs randomly.

According to Dulay, Burt, and Krashen (1982), stated based on surface structure taxonomy, there are several types of error, such as omission, addition, misformation and misordering.

First, omission happens when an essential item (morpheme) is absent in the sentence. Those essential morphemes are content words (noun, verb, adjective, and adverb) and grammatical word, such as noun and verb inflection (-s, -ed, -ing), the article (a, an, the), verb auxiliary (is, am, are, will, can, must etc), preposition (in, on, at, etc). Language learner mostly omits the grammatical morphemes, and it makes a wrong sentence.

Second, Addition error is an opposite of omission. This kind of error happens when an item appears in a sentence but the item can appear in the sentence. There are three types of addition errors such as double marking, regularization and simple addition. (a) Double marking is kind of error which happens because of the existence the same items for marking the same feature. The example: "She doesn't kicks the ball", in this sentence, there is an item that must not appear which is " $\mathrm{s}$ " for indicating simple present tense. It should be "She doesn't kick the ball". (b) Regularization errors occur when a morpheme is added to 
exceptional words, like fish, tea, etc. are not added by suffix -s or -es to make the plural forms. (c) Simple addition error refers to the use of an item which not should appear in wellformed utterance.

Third, misformation happens when users of language do not fully understand the grammar itself, so they build a wrong word or morpheme. Misformation errors are shown by the use of the wrong form of the morphemes or structure. There are three types of misformation error. (a) Regularization error happens when the use of regular marker place regular one. (b) This kind of error is really common happen in any stage of language acquisition. Archi-form error occurs in the selection of one number of a class of forms to represent others in the class. (c) Alternating error is caused by the learners' vocabulary and grammar development.

Fourth, misordering errors are characterized by the incorrect placement of a morpheme or group of morphemes in an utterance. It occurs systematically for both L1 and L2 learners in constructions that have already been acquired.

Brown (2000) sates that there are several sources of errors such as interlingual transfer, intralingual transfer, context of learning, and communication strategies. (a) Interlingual transfer occursbecause of first language or native language interference. In this point, the target language is not familiar to the leaner and only the previous language system is familiar. They use previous language system to produce an idea in the target language. For example, in Indonesian "Diagadiscantik", it becomes an intralingual error when the sentence is translated literally like "She girl beautiful". (b) Intralingual transfer happens because of the development of a new linguistics system. There is overgeneralization of the target language. For example, there is overgeneralization of plural form of a noun, they might think all of plural form of a noun it only adds suffix -e/es, it likes mouse becomes mouses, man becomes mans or child becomes childs. Moreover, Richards (1971) sates that there are several types of intralingual transfer, such asovergeneralization error, ignorance of rule restrictions, false hypothesis, and incomplete application of rules. Overgeneralization error is an error of using the rule of target language which ignores of rule restrictions, incomplete in applying the rules. Ignorance of rule restrictions covers the application of the rule which is not applicable in the right context. The application of the rule creates different perfective. The example is "He made me to go rest", the application "made" is not appropriate based on context. It should be "He asked/wanted me to go"). Then, incomplete application of rules means application of the rule is not complete. The learners fail to apply the rule in creating sentences. It makes the structure of the sentence is not appropriate. For the example in question form sentence: "You like to sing?" in place of "Do you like to sing?". The last, False hypothesis shows about the lack comprehension of the target language by the learners. This point, the understanding of target language by the leaners is not full. (e.g. the use of "was" as a marker of past tense in "One day it was happened"). (c) Context of learning can be called overlaping both types of transfer or error in the concept of learning. For Example, in the classroom, the teacher taught the wrong concept or the book regarding the context. (d) Communication strategies are used to deliver the meaning of a new language.Those strategies are substitution, coining new words, asking for clarification, literal translation and switching to the first language. In using communication strategies, sometimes the choice of words is not correct. It causes incorrect sentence grammatically.

There are three research questions in this study, (1) what are the language functions used by tour guides in DanauTamblingan? (2) what types of error in language functions which are made by the local guides in DanauTamblingan? (3) what are the sources of error committed in language functions by tour guides in DanauTamblingan? Based on those research questions, there were three purposes of this study, (1) to identify the language functions that are used by local guides in DanauTamblingan, (2) to analyzed types of errors in language functions which are made by the local guides in DanauTamblingan, and to identify the sources of errors committed in language functions by local guides in DanauTamblingan. 


\section{Method}

According to Creswell (2012), there are five steps of data collection. The first step of data collection was to determine participants and site that would be studied. In this case, the researcher identified the participants, and place on purposeful sampling. There were some criteria for choosing the participants such as the subject must be willing to be informant, the subject must be cooperative to support the researcher, the subject also must be honest and friendly.

The second step was to obtain the access to the participants and places by asking permissions. In order to collect the data, the permission was needed by the researcher to begin the research. The researcher needed greater access to the site in order to do interviews and observe them. Here, the researcher asked permission from the campus to conduct a research. Then, the researcher asked permission to the group of local guides in Danau Tamblingan by sending a permission letter. Those permissions were accessed by the researcher.

The third step was to consider what types of information that would be the best answer to the research questions. Here, the researcher collected the data in form of language expressions of the local guides and also the researcher needed some pictures to support the study.

The fourth step is the researcher designed instruments for collecting and recording the information at the same time.

The last step was the researcher administers the data collection with special attention to potential ethical issues that may arise. The researcher considered the process of collecting data in a way that is ethical to individuals and to research sites. It means there is no participant and site being harmed of the study.

In the process of data collection, there were several ways in collecting data, the observation technique was used for collecting the sentence forms and the language functions that were used by the local guide. The researcher came to the field and asked permission to observe the activity of the local guides which focused on the interaction with foreign tourists. Then, Interview, the researcher asked the questions based on the interview guide about the way of the local guides serve the foreign tourists. it focused on the source of the errors committed by the local guides in handling the tourists.

This research focused on analyzing the used of English by tour guides in Danau Tamblingan. The researcher had decided the subjects or the source of this study were 3 the local guides in Danau Tamblingan.

The researcher used an Interactive Data Analysis Model based on Miles and Huberman (1994). There are four steps to analyze the data, such as data collection, data display, data reduction, and drawing conclusion and verification. The steps of data analysis could be seen as in the following diagram.

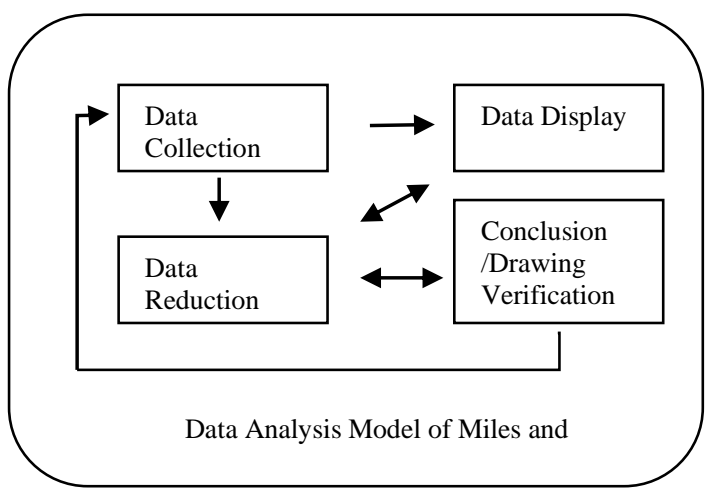

Third, after the data reduction, the researcher classified the data in the form of table. The data were classified into some tables. Those were in the form of language functions and language expressions. There were some language functions based on Savignon's theory, 
Spratt's theory and Sucipta's findings. Those were used to analyzed the data such as agreeing, disagreeing, greeting, giving command, leave taking or saying goodbye, describing or explaining something, apologizing, advising, thanking, interrupting, clarifying, inviting, refusing, self-introduction, offering something, asking information, giving information, indicating something, asking permission, giving suggestion, and telling prohibitio. The language expressions were analyzed and classified into types of errors based on Dulay, Burt and Krashen' theory and sources of errors based on Brown's theory. There were some types of errors used, such as omission, addition, misordering, and misformation. There were some sources of errors used to analyze the data, such as interlingual transfer, intralingual transfer (ignorance of rule restrictions, incomplete application of rules, and false hypothesis) and communication strategy. After analyzing the error, the researcher calculated the error to find the percentage of the error by using the formula below.

$$
\mathrm{P}=\frac{n 1}{\Sigma N} \times 100 \%
$$

In which, the information of formula:

$\mathrm{P} \quad=$ Percentage each grammatical error

$\mathrm{n} 1=$ Total of grammatical error committed by the local guide in each type

$\Sigma \mathrm{N} \quad=$ Total of the whole error

The last one was developing a conclusion and verification. In here, the analysis began to develop conclusions of the study. The conclusions were verified, the validity was examined through reference to the existing field notes or further data collection.

\section{Finding and Discussion}

The first research question was intended to find out the language functions used by the local guides in handling the tourists in DanauTamblingan. There were 14 language functions used by the local guides in Danau Tamblingan in handling tourists. Those language functions were: (1) advising (2) thanking, (3) greeting, (4) refusing, (5) self-introduction, (6) offering something, (7) asking information, (8) giving information, (9) explaining something, (10) giving suggestion, (11) giving command, (12) telling prohibition, (13) apologizing, and (14) saying goodbye. Then, there were 7 language functions that were not used by the local guide, such as: agreeing, disagreeing, inviting and interrupting. The most frequent language function used the local guides was function for explaining something that related to the trekking.

The second research question was intended to investigate the types of errors on the spoken language expressions by the local guides in DanauTamblingan, Buleleng. Based on those language functions and their expressions, there were found 579 errors committed by the local guide which categorized into four types of errors such as omission for 365 errors or $63,0 \%$, addition for 103 errors or $19,0 \%$, misformation for 93 errors or $15,0 \%$ and misordering for 18 errors or $3,0 \%$. It can be seen in the table below.

Table 1. The result analysis of grammatical error committed by the local guides in DanauTamblingan.

\begin{tabular}{|c|c|c|c|c|}
\hline No. & $\begin{array}{l}\text { Types of } \\
\text { Error }\end{array}$ & $\begin{array}{l}\text { Total } \\
\text { of } \\
\text { Error } \\
\text { s }\end{array}$ & $\begin{array}{l}\text { Perce } \\
\text { ntage }\end{array}$ & Rank \\
\hline 1. & Omission & 365 & $63.0 \%$ & 1 \\
\hline 2. & Addition & 110 & $19.0 \%$ & 2 \\
\hline 3. & $\begin{array}{l}\text { Misformati } \\
\text { on }\end{array}$ & 86 & $15,0 \%$ & 3 \\
\hline
\end{tabular}




\begin{tabular}{lllll}
\hline 4. & Misorderin & 18 & $3.0 \%$ & 4 \\
& $\mathrm{~g}$ & & & \\
Total & & 579 & $100 \%$ & \\
\hline
\end{tabular}

Based on the analysis in the omission error, there were several kinds of omission occurred, such as omission of be, omission of auxiliary verb, noun inflection in plural noun, omission of subject, verb inflection in simple present tense, omission of preposition, omission of article, omission of object, omission of conjunction, omission of verb, omission of ed/d in making passive voice, omission of noun, omission of -ing in making gerund, and omission of $\mathrm{ed} / \mathrm{d}$ in making past tense. Those kinds of omissions were produced by the local guides. The following sentences are the examples of omission error committed by the local guides

a. Why $\checkmark$ we call it parasite?

b. This $\checkmark$ Tamblingan lake

In first sentence, the local guide omitted "do" as an auxiliary verb in forming a question, and in the second sentence, the local guide omitted "is" as a be in forming a sentence. Those sentences should be like "Why do we call it parasite?" and "This is Tamblingan lake".

In addition error, there were two types of addition error were committed by the local guides, namely simple addition and double marking. These following sentences are the examples of addition error.

a. We will (be) start the boat from the second point

b. Actually, luwak, they need (more) wider place

The first example is simple addition error, the local guide added "be" which should not appear in the sentence. The second example is double marking error. The word "more" has the same function with "er" in word "wider". Those sentencesshould be "We will start the boat from thesecond point" and "Actually, luwak, they need a wider place".

In misformation error, there was only one types occurred, it was alternating. All of the local guides did alternating errors. These are the example of the error committed by the local guide.

a.[you] driver should pick up you there

b.So, how [is] the walk so far? Good?

Based on the example of alternating above, it shows that all the local guides did alternating errors in forming a sentence. In the first sentence, the local guide made an error in the used of "is". Based on the situation, the local guide about the activity in the past so it should be "was". Then, the local guide made an error in using a possessive pronoun, it should be "your". The sentences should be "Yourdriver should pick up you there" and "So, how wasthe walk so far? Good?"

In misordering error, all the local guides made misordering word(s) in making a sentence. These are the examples of the misordering errors committed by the local guides.

a.We have a lot of points water to supply to the irrigation.

b. we have a grass land very beautiful when in normal day.

Those expressions above show that all the local guides did misordering errors in making sentences. The local did an misordering error in "points water", it should be "water points". Then, the local guide made a misordering error on the phrase "grass land very beautiful" it should be "very beautiful grass land". These sentences should be "We have a lot of water points supply to the irrigation." and "We have a very beautiful grass landwhen in normal day".

Then, those types of error committed by the local guides in handling the tourists were caused bythe 3 sources of error. The biggest source of the error was intralingual transfer with 536 errors. The second source was interlingual transfer with 24 errors and the smallest source of error was communication strategy with 19 errors. Interlingual transfer leaded the sentences that were produced by local guides like using the structure of the previous language or first language which is Indonesian.Intralingual transfer also leaded the error committed by the local guides, it happened because the local guides did not understand the 
English well so they ignored the rule restriction, failed to hypothesize the concept, and uncompleted in applicating the rule. Communication strategy also leaded the errors of the local guides, here they produce their ideas directly. They made literal translation and also combine Indonesia word with English. It caused the error happened.

The results of this study were compared and contrasted with some previous studies. Andayani (2013) found 12 language functions used in the conversation. There were only 9 language functions that are the same as this study such as for information, giving situation, denying something, offering something, suggestion, helping, greeting and thanking. There were 3 different language functions found, such as certain or uncertain, expressing hope and repeating. Then, Budaartha (2016) found only 7 language functions that used in the conversation, only one language function deferent that he found in his study which is disagreeing and the rest are the same. Kanya (2017) found six language functions such as function of greeting, function of giving information, function of offering something, function of thanking, function for apologizing and function for saying good bye in handling the tourist by the tour guide. Those 6 language functions were found also in this study. Moreover, Sucipta (2016) found 12 language functions used by the local guides. In line with this study, there were 10 same language functions used by the local guides, such as greeting, selfintroducing, offering something, asking for information, giving information, explaining something, giving suggestion, telling prohibition, apologizing, thanking and saying goodbye. There were 2 different language function found such as indicating something and asking for permission answering question.

Furthermore, Putri (2016) found 1000 utterances were grammatical error committed by the tour guides in Keraton Yogyakarta. in line with this study the findings were analyzed by using Dulay, Burt and Krashen's theory. She found the highest types of error was omission with $40.4 \%$, in $n$ this study the omission error was $63,04 \%$. In contrast with the sources of errors in her study, she found errors occurred because of the lack understanding of grammar by tour guides meanwhile in this study, there were 3 sources as mentioned above. Alfiyani (2013) found the biggest error occurred were omission, then addition, misformation and misordering. In contrast with this study, the sources of the errors were developmental error, ambiguous error, interlingual error and unique error meanwhile in this study only three sources of error intralingual, interlingual and communication strategy. Maniam\& Rajagopal (2016) also conducted a study error analysis using surface structure taxonomy. In their study, they found only three types error, namely omission, addition, and misformation meanwhile, in this study found four types of errors. The source of error was a bit different, they found application of translation as source of error.

\section{Conclusions And Suggestions}

Based on the result of the analysis, first, it can be concluded that there were 14 language functions used by the local guides in handing tourists in Danau Tamblingan. The local guides used function for (1) advising for once time (2) thanking for 5 times, (3) greeting for 3 times, (4) refusing for 1 time, (5) self-introduction for 3 times, (6) offering something for 3 times, (7) asking information for 42 times, (8) giving information 130 times, (9) explaining for 90 times something, (10) giving suggestion for 1 time, (11) giving command 7 time, (12) telling prohibition 3 times, (13) apologizing 3 times, and (14) saying goodbye for 3 times.

Second, there were four types of error committed by the local guides in Danau Tamblingan namely; Omission error, addition error, misformation error and misordering error. The most error occurred was omission error with 365 error or $63,04 \%$. It was followed by addition error with 103 error or $17,80 \%$. Then, it was followed by misformation with 93 errors or $16,06 \%$. The smallest error occurred was misordering with 18 error or $3,10 \%$.

Third, based on the result of the analysis, the sources of errors were caused by intralingual transfer, interlanguage transfer and communication strategy. There

were 536 error caused by intralingual transfer, it was followed by interlingual transfer with 24 error and communication strategy was 19 errors. 
It can be suggested that all the local guides should know those language functions used in handling the tourists. By knowing the language functions, it will lead the communication effectively. Moreover, the English expressions used by the local guides in handling tourist in Danau Tamblingan still came with errors. In every communication, considering the expressions used and the grammar in the communication is really important for every tour guide because it will lead a good communication to avoid misunderstanding by using proper grammar and proper language expressions.

For the other researchers are expected to conduct a deeper study related to error analysis of the language functions in different area because it is really important to the tourism itself.

\section{References}

Alfiyani, L. M. (2013). An Aalysis of Grammatical Error in Writing Among The Second Semester Student of English Department of Yogyakarta State University in the Academic Year of 2011/2012. Yogyakarta: Yogyakarta State University.

Al-khresheh, M. H. (2015). A Review Study of Interlanguage Theory. International Journal of Applied Linguistics \& English Literature, 123-131.

Andayani, L. A. (2013). An Analysis of Language Function Found in English Used by Receptionists in Bali Brasco. Denpasar: Mahasaraswati University.

Ananta, Made. 2011. An Analysis of step and Language Expressions Used by Guest Service Executives in Handling Complaint at Tunehotels.comKuta. Final Project. Jurusan D3 Bahasa Inggris. UndikshaSingaraja.

Brown, H. D. (2000). Principle of Language Learning and Teaching. New York: Longman.

Budaartha, I. N. (2016). The English used by street vendors in Banjar hot Spring, Bali. Singaraja: Ganesha University of Education.

Chilembwe, J. M., \& Mweiwa, V. (2014). Tour Guides: Are They Tourism Promoters and Developers? Case Study of Melawi. Impact: Ijrbm, 2(9), 29-46.

Creswell, J. W. (2012). Research Design Qualitative, Quantitative, and Mixed Methods Approaches. California: SAGE.

Dulay, H., Burt, M., \& Krashen, S. (1982). Language Two. New York: Oxford University Press.

Gass, S. and Selinker, L. (2001). Second language acquisition: An introductory course. Mahwah NJ: LEA, Chapter 3,2.

Heydari, P., \& Bagheri, M. S. (2012). Error Analysis: Sources of L2 Learners' Errors. Theory and Practice in Language Studies, 1583-1589.

John, A., \& Wong, K. K. (2001). Case study on tour guiding: professionalism, issues and problems. Tourism Management, 551-563.

Kirn, E., \& Jack, D. (2002). Interactions I Grammar. New York: McGraw-Hill.

Maniam, M., \& Rajagopal, P. (2016). Simple Past Tense Errors Based on Surface Structure Taxonomy in ESL Malaysian Undergraduates Writing. Global Journal of Advanced Research, 3(6), 547-553.

Miles, M. B. (1994). Qualitative Data Analysis: An Expanded Sourcebook. California: SAGE.

Newmeyer, J. F. (2003). Grammar is grammar and usage is usage. Retrieved from Washington: http://www.englishgrammar.com//grammar is usage//9087 
Pelin, M. (2010). Interlangugage or Intralanguage? Interlangugage or Intralanguage? A Study of Errors in English Essays Produced by Swedish Pupils. Högskolan i Halmstad Sektionen för Humaniora Engelska, 61-90.

Pond, K. (1993). The professional guide: dynamic of tour guiding. New York: Van Nostrand Reinhold.

Putri, F. I. (2016). Grammatical Errors Made by The Tour Guides in Kraton Yogyakarta . Yogyakarta: Universitas Gadjah Mada.

Richards, J. C. (1971). A non-contrastive approach to Error Analysis. English Language Teaching Journal, 204-219.

Sawalmeh, M. H. (2013). Error Analysis of Written English Essays: The case of Students of the Preparatory Year Program in Saudi Arabia. English for Specific Purposes World, 117.

Spratt, M., Pulverness, A., \& Williams, M. (2005). The TKT ( Language Knowledge Test Course). Cambridge: University Press.

Sucipta, I. B. (2016). A Description of Language Used by The Local Guides In Explaining About Batur Tample in Kintanami Bangli. Singaraja: Undikhsa.

Sugiyono. (2010). Metode Penelitian Pendidikan Pendekatan Kuantitatif, kualitatif, dan R\&D. Bandung: Alfabeta.

Suhono. (2016). Surface Strategy Taxonomy on the EFL Students' Composition: A Study of Error Analysis. Iqra', 1-27.

Tarone, E. (2006). The Interlanguage Hypothesis. Science Direct, 747-752.

Wedaj, S. (2015). Analyzing the Discourse of Tour Guiding Communication: The Case of Lalibela Rockhewn Churches. Addis Ababa: Addis Ababa University School of Graduate Studies Department of Foreign Languages and Literature.

Yurika Kanya, A. I. (2017). An Analysis of Language Function and Expression Used By Tour Guide At Bali Best Memory Tour In Handling Tourist. Singaraja: Ganesha University of Education. 